\title{
SINERJITAS PESANTREN DAN PERGURUAN TINGGI STAI NAZHATUT THULLAB SAMPANG DALAM PEMBERDAYAAN MASYARAKAT PERSPEKTIF MANAJEMEN
}

\author{
Munib \& Ismail \\ STAI Nazhatut Thullab Sampang \\ Email: munib.cahayailmu@gmail.com
}

\begin{abstract}
Abstrak:
Pendidikan nasional berfungsi mengembangkan kemampuan dan membentuk watak serta peradaban bangsa yang bermartabat dalam rangka mencerdaskan kehidupan bangsa, bertujuan untuk berkembangnya potensi peserta didik agar menjadi manusia yang beriman dan bertakwa kepada Tuhan Yang Maha Esa, berakhlak mulia, sehat, berilmu, cakap, kreatif, mandiri dan menjadi warga negara yang demokratis serta bertanggung jawab. Keberhasilan pendidikan pada semua jalur, jenis, dan jenjang pendidikan dalam pemberdayaan masyarakat akademis (santri) sangat dipengaruhi adanya lembaga pendidikan yang sesuai dengan kebutuhan masyakat yang berada di lingkungan pesantren. oleh sebab itu perlu adanya sinerjitas pesantren dan perguruan tinggi dalam pemberdayaan masyarakat. Tujuan kami dalam penulisan artikel ini adalah untuk meneliti dan mengetahui sejauh mana adanya sinerjitas pesantren dan perguruan tinggi dalam pemberdayaan masyarakat dalam perspektif manajemen di STAI Nazhatut Thullab Sampang.
\end{abstract}

Kata Kunci: Sinerjitas Pesantren, Manajemen, Perguruan Tinggi, Pemberdayaan Masyarakat.

\begin{abstract}
:
National education function to develop ability and form the character and civilization of dignified nation in order to educate the life of the nation, aims to the development of the potential of learners to become human beings who believe and pious to God Almighty, noble, healthy, knowledgeable, skilled, creative, independent and become a democratic and responsible citizen. The success of education in all pathways, types, and levels of education in the empowerment of academic societies (santri) is strongly influenced by educational institutions in accordance with the needs of the communities in the pesantren environment. therefore the need for synergy of pesantren and universities in community empowerment. Our goal in writing this article is to examine and find out the extent to which the synergy of boarding schools and universities in community empowerment in management perspective in STAI Nazhatut Thullab Sampang.
\end{abstract}

Keywords: Pesantren Synergy, Management, Higher Education, Community Empowerment. 


\section{Pendahuluan}

Seiring perkembangan peradaban bangsa Indonesia dan modernisasi sebagai tren masyarakat global mengalami tantangan yang cukup besar sekaligus akan menjadi ancaman apabila tidak terantisipasi dengan baik dan professional. sejumlah kemudahan hadir dihadapan kita untuk memanjakan manusia. Tetapi problema juga muncul sebagai dampak dari pembangunan itu sendiri. Perubahan pola dan gaya hidup masyarakat akan menyentuh seluruh warga Indonesia. Lebih -lebih pesantren dan perguruan tinggi islam merupakan salah satu lembaga pendidikan yang tidak hanya fokus pada pendidikan agama dan moral, tetapi dituntut untuk berinovasi dengan mensijerjikan pendidikan pesantren dan perguruan tinggi dalam memberdayakan melalui tranformasi nilai-nilai, Norma Agama, ilmu tegnologi dan sains modern.

Pendidkan Pesantren dan perguruan tinggi adalah sumber dari peradaban itu sendiri baik pesantren yang melaksanaka pendidikan formal atau non formal harus mampu mengantarkan peserta didiknya dan membekali dengan berbagai keterampilan,keahlian khusus untuk masa depan yang gemilang. Dan pesantren serta perguruan tinggi harus menganut pada kurikulum yang sesuai dengan perkembangan zaman kurikulum yang sudah baku. Selain itu pesantren serta perguruan tinggi harus memberikan fasilitas yang dapat membantu lancarnya proses belajar mengajar tak kalah penting dari itu sekolah harus mampu mendatangkan guru yang proposinal.

STAI Nazhatut Thullab Sampang merupakan salah satu perguruan tinggi yang secata letak giografis berada ditempat yang amat strategis dipinggiran kota kabupaten sampang.

Berdasarkan uraiaian di atas dan sesuai dengan fakta di lapangan, maka yang menjadi dasar pemikiran penulis untuk dikaji dan diteliti sebagai berikut : Bagaimana sinerjitas pesantren dan perguruan tinggi di STAI Nazhatut Thullab Sampang. Apa dampak sinerjitas pesantren dan perguruan tinggi dalam pemberdayaan masyarakat. Dan bagaimana sinerjitas pesantren dan perguruan tinggi dalam perspektif manajemen di STAI Nazhatut Thullab Sampang

\section{Sinerjitas Pesantren dan Perguruan Tinggi}

Mengantisipasi perubahan-perubahan yang begitu cepat serta tantangan yang semakin besar dan kompleks, tiada jalan lain bagi lembaga pendidikan Islam yaitu pesantren dan perguruan tinggi untuk mengupayakan segala cara untuk meningkatkan daya saing lulusan serta produk-produk akademik lainnya, yang antara lain dicapai melalui peningkatan mutu pendidikan. ${ }^{1}$ Peningkatan kualitas pendidikan merupakan suatu proses yang terintegrasi dengan proses peningkatan kualitas Sumber Daya Manusia(SDM) itu sendiri. Menyadari pentingnya proses peningkatan kualitas Sumber Daya manusia(SDM), maka pemerintah bersama kalangan swasta sama-sama telah dan terus berupaya mewujudkan amanat tersebut sebagai upaya pembangunan pendidikan yang lebih berkualitas antara

\footnotetext{
1 Terkait dengan itu, Ali Bin Abi Thalib berpesan bahwa, "Ajari anak-anakmu karena mereka akan hidup di zamannya yang berbeda dengan zaman kita sekarang". Ini adalah konsep pemikiran modern yang bersifat futuristic. Islam mengajak dunia pendidikan memasuki era modern dan fleksibel dalam menghadapi tuntunan perubahan dan tantangan masa depan.
} 
lain melaui pengembangan dan perbaikan kurikulum, integrasi ilmu agama dan ilmu umum dan sistem evaluasi, perbaikan sarana pendidikan, pengembangan dan pengadaan materi ajar, serta pelatihan bagi dosen dan tenaga kependidikan lainnya.

Pesantren merupakan centre pendidikan Islam di Indonesia, tempat para santri menuntut ilmu. Perkataan santri itu sendiri digunakan untuk menemukan pada golongan orang-orang Islam di jawa yang memiliki kecendrungan lebih kuat pada ajaran Agamannya, ada yang mengatakan bahwa pendidikan Pesantren ini merupakan asli tradisi Indonesia, sehingga pendidikan pondok Pesantren ini merupakan ciri yang has Indonesia. Dalam sebuah pondok Pesantren tentunya terdapat banyak sekali elemen-elemen yang keberadaannya saling terkait dan sangat terikat antara yang satu dengan yang lainnya. Seperti kiai, asatidz (para guru), dan juga para santri (sebagai peserta didik) serta adanya kitab-kitab klasik (kitab kuning) dan sebagainya. Pendidikan Pesantren dan kitab kuning itu merupakan sebuah hal yang sangat berkesinambungan dan merupakan perkembangan tradisi keilmuan Islam khususnya di Indonesia. Beberapa aliran kemudian muncul seperti modernis, reformis dan fundamintalis. Selain itu, upgrading lembaga pendidikan pesantren tidak hanya terbatas kepada pendidikan formal keagamaan semata, melainkan juga sudah mendirikan perguruan tinggi yang berupa sekolah tinggi, institute dan bahkan universitas. Sinergitas lembaga pendidikan pesantren dan perguruan tinggi ini menjadi menari perhatian ketika kedua lembaga ini saling melengkapi antara yang satu dengan yang lainnya. ${ }^{2}$

Dalam upaya menciptakan pengembangan ilmu yang menyangkut relevansi ilmiah dan relevansi sosial untuk menjadi solusi yang efektif dan solutif bagi permasalahan yang berkembang di tengah-tengah masyarakat serta Dalam upaya meningkatkan mutu dan peranan pendidikan yang bisa menyeimbangkan antara perguruan tinggi dan pesantren dalam pemberdayaan masyarakat. Sekolah Tinggi Agama Islam Nazhatut Thullab Sampang menggelar Seminar Nasional Dengan Tema "Sinergitas Pesantren dan Perguruan Tinggi dalam Pemberdayaan Masyarakat" Acara Yang dikemas dalam bentuk Seminar Nasional dihadiri oleh Mohammad Nuril Huda, M.Pd (Kopertais wilayah empat surabaya), Prof. Dr. KH. Abd. A’la, M. Ag selaku (Rektor Uin Sunan Ampel Surabaya) selaku Narasumber. Pada seminar ini hadir pula Pimpinan PonPes Nazhatut Thullab Prajjan Camplong Sampang (KH. Muhammad Mu'afi) yang dalam Sambutannya KH. Muhammad Mu'afi mengharap bahwa dengan adanya Seminar Nasional tersebut mampu menciptakan kerjasama yang baik antara pesantren dengan Pihak Perguruan Tinggi dalam tatakelola sitem pendidikan sehingga dengan adanya kerjasama dapat membangun komunikasi yang bisa bermanfaat bagi masyarakat.

Dalam materinya, Prof. Abd. A'la menyampaikan bahwa Perguruan tinggi itu harus ada korelasi dengan pesantren, karena sudah banyak pesantren yg mnghasikan kader dari berbagai bidang baik ekonomi, sosial ,budaya dan agama. Ini sebagai bentu bahwa pesantren adalah tempat pengkaderan terbaik. Dan pada prinsipnya perguruan tinggi harus mampu disinergikan dengan pesantren bahkan tingkat perguruan tinggi masih kurang optimal kalau bisa harus lebih layak danpesantren harus bisa disinergikan dengan universitas. Harapan saya STAI

${ }^{2}$ M. Sahibuddin, "Pesantren dan Pendidikan Tinggi" Jurnal Penelitian dan Pemikiran Keislam, Juli 2017.Vol.4.No.2, 91 
Nazhatut Thullab Sampang bisa menjadi universitas yang bisa bersaing dikabupaten Sampang.

Dalam kesempatan tersebut KH. Toyyib Madani selaku Ketua pimpinan STAI Nazhatut Thullab mengatakan bahwa beliau sengaja mengadakan Seminar Nasional tersebut dan berharap bahwa Perguruan tinggi yang ada disampang bisa lebih memahami tentang Korelasinya terhadap keberadaan pesantren yang ada di kabupaten Sampang, Sehingga pesantren dan perguruan tinggi dapat bersinergi dalam membangun relevansi pendidikan yang lebih baik dan dapat meningkatkan kualitas pendidikan yang bisa memberdayakan masyarakat sekitarnya.

Pendirian Pondok Pesantren Nazhatut Thullab Prajjan Camplong Sampang Madura, bermula dari peristiwa "Babat Ranah Prajjan" oleh K. Abdul "Allam yang mempunyai nama asli Pang Ratoh Bumi yang berasal dari ujung wetan dari Pulau Garam Madura yaitu Kabupaten Sumenep. Nama Abdul 'Allam adalah pemberian dari Hadratu Al Syaikh Aji Gunung Sampang sewaktu beliau belajar dan nyantri padanya yang ditemani oleh dua orang sahabat sejatinya yang berasal dari Pulau Jawa yang kemudian mendapat julukan Buju' Napo dan seorang lagi berjuluk Gung Rabah Pamekasan. Menurut sebagian hikayat keberadaan K. Abd. 'Allam (Pang Rato Bumi) bersamaan dengan penangkapan dan pengasingan Cakra Ningrat II oleh Koloneal Belanda. Hubungan keduanya sangat intens sekali dimana Pang Rato Bumi selalu menemui dan mengadakan kontak komunikasi dengan Pangeran Cakraningrat II di pengasingannya. Hal itu dilakukan dalam rangka membahas perjuangan rakyat untuk melawan penjajah Belanda pada masa itu. (H. Abdurrahman Sumenep).

Nama Nazhatut Thullab berasal dari bahasa arab yang berarti : Nazhatu artinya Kebun atau Taman dan Al Thullab artinya Pelajar atau Siswa.Jadi Pondok Pesantren Nazhatut Thullab adalah Taman Siswa. Penamaan ini mungkin saja ada kaitannya dengan istilah Taman Siswo yang didirikan oleh Ki Hajar Dewantoro (Pendiri Taman Siswa). Sejak periode inilah Pondok Pesantren Nazhatut Thullab mulai menata diri. Bahkan, sejak masa itu, Pondok Pesantren ini menjadi Pioneer sistem pendidikan klasik, yang selanjutnya telah melahirkan berbagai lembaga pendidikan dengan system yang sama pada masanya. Hingga kini Pondok Pesantren Nazhatut Thullab telah berusia 3 (tiga) Abad lebih, dihitung sejak terjadinya peristiwa Babat Tanah Prajjan, yaitu pada tahun $1702 \mathrm{M}$.

Mulai dari periode ke-9 (Sembilan) itulah Pondok Pesantren Nazhatut Thullab mengembangkan dengan mendirikan beberapa unit lembaga pendidikan formal yang berinduk kepada beberapa Departemen antara lain : Departemen Pendidikan dan Kebudayaan Nasional, Departemen Agama dan Departemen Kesehatan dengan mendirikan Madrasah Diniyah (didirikan sejak Tahun $1702 \mathrm{M}$ ), MTs NATA (Didirikan Pada Tahun 1969),SMP NATA (Didirikan pada Tahun 1995),MA Keagamaan NATA (Didirikan Pada Tahun 2001), SMA NATA (Didirikan pada Tahun 1988), SMK NATA (Didirikan pada Tahun 2003), STITNAT (Sekolah Tinggi Ilmu Tarbiyah Nazhatut Thullab ). Didirikan pada Tahun 1988 dan pada tahun 2010 alih status menjadi STAI NATA dengan masuknya program studi baru yaitu al-ahwal al-syahsyiyah (hukum perdata) dan ekonomi syari'ah dan AKPER NATA Sampang (Didirikan pada Tahun 2002).

Disamping membekali santrinya dengan Pendidikan Agama dan Umum Pondok Psantren Nazhatut Thullab juga membekali para santrinya dengan 
berbagai ketermpilan guna mencapai tujuan Pendidikan Berbasis Komperhensif (PBK) dan Pendidikan Berbasis Kultural (PBKu) antara lain; Bordir, Jahit, Tata Boga, Tata Rias, Kaligrafi, Seni Hadrah, PMR dan lain-lain yang cukup mendukung dengan pola Pendidikan tersebut.

Visi yayasan pondok pesantren Nazhatut Thullab adalah "Terwujudnya generasi ber-Iman dan ber-Taqwa, ber-Ilmu Pengetahuan dan ber-Teknologi yang Ber-Akhlaqul Karimah". Dan Misinya adalah: Menyelenggarakan Pendidikan yang berakar pada nilai-nilai agama dan akhlakul karimah. Menyelenggarakan pendidikan yang berorientasi pada mutu sesuai dengan perkembangan ilmu pengetahuan dan teknologi. Pembekalan Live skill untuk menjadi generasi yang siap pakai dan siap menghadapi tantangan zaman.

Adapun Tujuan Umum penyelenggaraan pendidikan formal dan pondok pesantren di Yayasan Pondok Pesantren Nazhatut Thullab adalah "Menghasilkan generasi yang mengedepankan iman dan taqwa kepada Allah SWT, ilmu pengetahuan dan teknologi, Akhlakul Karimah, menjadi pribadi beragama yang mandiri, cerdas dan kompetitif sebagai masyarakat berbangsa dan bernegara". Dan tujuan khusus penyelenggaraan pendidikan formal dan pondok pesantren di Yayasan Pondok Pesantren Nazhatut Thullab adalah : a. Melaksanakan sistem integrasi dalam perencanaan, proses dan evaluasi pembelajaran pada pendidikan umum dengan program pondok pesantren. b. Melaksanakan pembelajaran yang berbasis informasi dan teknologi. c. Mengintegrasikan pendidikan kecakapan hidup dengan semua mata pelajaran baik di pendidikan umum maupun di pendidikan pesantren. d. Membentuk jiwa kompetitif dengan mengadakan dan berpartisipasi pada kegiatan olimpiade MABIFIKI (Matematika, Bahasa, Biologi, Fisika dan Kimia) dan kegiatan-kegiatan lain dalam ruang lingkup kecakapan (lomba seni dan olah raga, lomba bidang keagamaan serta lomba sastra dan karya tulis ilmiah).

Pesantren dan perguruan tinggi sebagai lembaga pendidikan yang bersifat otonom harus mampu berbenah diri dalam mencapai kualitas pendidikan yang diharapkan oleh masyarakat serta juga sebagai kontribusi terhadap sistem pendidikan nasional dengan kemapuan mewujudkan Sumber Daya Manusia(SDM) yang handal. Di sisi lain pemerintah tidak menetapkan pesantren sebagai lembaga pendidikan yang sekunder dalam sistem pendidikan nasional, sikap ini akan menjadi pola pemberdayaan yang balance antara lembaga yang dikelola negeri dan swasta. Dalam arti lain pesantren dan perguruan tinggi harus saling bersinerji dan harus terus mengalami perkembanagan dan peka terhadap perkembangan zaman untk mncetak generasi-generasi bangsa yang lebih baik. Lembaga pendidikan seperti pesantren Nazhatut Thullab dan STAI Nazhatut Thullab sampang adalah salah satu pesantren yang melakukan sinerjitas anatara pesantren dan perguruan tinggi.

Keberadaan pondok pesantren di tengah pergulatan masyarakat informasional pesantren, pesantren"harus dipaksa" memasuki ruang kontestasi dengan institusi pendidikan lainnya. Terlebih dengan sangat maraknya pendidikan berlebel luar negeri yang menambah semakin ketatnya peraingan mutu lulusan (out-put) pendidikan kompetesi semakin ketat itu mendorong institusi pesantren untuk mempertaruhkan out-put pendidikannya agar tetap unggul dan tetap menjadi pilihan masyarakat, terutama umat islam. Ini mengindikasikan bahwa 
pesantren perlu banyak melakukan pembenahan internal dan inovasi baru agar tetap mampu meningkatkan mutu pendidikannya.

Itulah kondisi makro yang sekarang ini sedang menghimpit dunia pesantren. Apakah pesantren sekarang sudah berfikir tentang apa yang bisa diperbuat ditengah atmosfir kehidupan global seperti itu serta apa kontribusi yang bisa disumbangkan untuk terus andil dalam membentuk kpribadian bangsa atau bahkan apakah pesantren bisa bertahan ditengah hegemoni produk-produk pemikiran dan tata kekuatan argomentasi pemikiran.

Dengan demikian pesantren harus selalu meningkatkan kualitas para santrinya sihingga mampu untuk bisa mewarnai dalam kehidupan di masyarakat. Sebab bila para santri tidak bisa mengikuti laju perkembangan zaman yang semakin kompetitif ini, maka pesantren akan semakin ketinggalan dan akan semakin tidak mendapat perhatian dari kalangan orang-oarang akademis. Sesungguhnya dalam sistem pendidikan yang dikotomi ini melahirkan berbagai keahlian, baik dari ilmu agama maupun pengetahuan umum. Sementara yang ingin dikembanagkan adalah pengembangan keilmuwan, tanpa memandang ilmu itu adalah ilmu dunia dan ilmu akhirat, yang bernuansakan ajaran islam. ${ }^{3}$

Agar Ilmu Pendidikan Islam tidak kehilangan daya tarik,kaitannya dengan kelembagaan dan fungsionalnya, diperlukanadanya perubahan paradigma, bangunan dan kerangka berfikir yangmemadai dalam penyelenggaraan pendidikan Islam. Diperlukan pendirian mengenai pandangan manusia, masyarakat dan dunia.Manusia diciptakan didunia diberi tugas Allah sebagai khalifah.Manusia mendapatkan wewenang dan kuasa untuk melaksanakan pendidikan terhadap dirinya sendiri. Dengan demikian, pendidikan merupakan tanggung jawab manusia sendiri untuk dapat mendidik dirinya sendiri, memahami hakikat kemanusiaannya, hakikat hidupdan kehidupannya serta tujuan dan tugas dalam kehidupannya yangkemudian dikenal dengan istilah ontologis. ${ }^{4}$

Ilmu-ilmu keislaman pada dasarnya secara akademik dapat dibagi menjadi tiga bidang keilmuan Islam; pertama, Ilmu Islam normatif, kedua, Ilmu Islam historis, dan ketiga, Ilmu Islam multidisipliner. Studi Islam yang bercorak normatif, kajian yang dilakukan lebih bersumber kepada teks-teks agama Islam, misalnya teks hadits, tafsir, fiqih, dan sebagainya. Kajian bidang Ilmu Islam ini memang menjadikan teks-teks ajaran Islam sebagai sasaran kajiannya. Sedang studi Islam yang bercorak historisita, kajiannya lebih menjadikan fenomena

sosial sebagai sasaran kajiannya. Di sini terdapat sejarah Islam, kebudayaan Islam, antropologi, psikologi, ilmu hukum, politik dan sebagainya. Pembidangan ini terkait dengan obyek kajian ilmu keislaman yang memang di satu sisi ada dimensi normativitasnya dan di sisi lain ada dimensi historisitasnya. Sementara yang ketiga, adalah bidang Ilmu Islam yang dikenal dengan "Ilmu IslamMultidispliner". 5

Jadi lembanga pendidikan Islam dalam hai ini pesantren Nazhatut Thullab perlu ada sinerjitas misalnya tidak hanya mengutamakan ilmu agama saja

\footnotetext{
${ }^{3}$ Mastuhu, Memberdayakan Sistem Pendidikan Islam,(Jakarta: PT Logos Wacana Ilmu,1999), hlm. 52.

${ }^{4}$ Moh wardi, "Problematika Pendidikan Islam dan solusi alternatifnya, (Perspektif Ontologis, Epistimologis dan Aksiologis)"Jurnal Tadrîs pendidkan agama islam STAIN Pamekasan Volume 8 Nomor 1 Juni 2013, 68

5 Fathul Mufid, “Integrasi Ilmu-ilmu Islam”Volume 1, No.1, Juni 2013, 65
} 
akatetapi ilmu-ilmu umum. Oleh sebab itu pesantren sebagai bagian dari pendidikan Islam harus senantiasa memerankan fungsi dan misi profesinya dalam peningkatan kualitas SDM-nya, baik dalam penguasaan sains dan tegnologi maupun dalam hal karakter, sikap dan moral, penghayatan dan pengamalan ajaran agama. Dengan kata lain, pesantren secara ideal harus berfungsi dan berperan membina dan menyiapkan santri yang berilmu, berteknologi, berketerampilan tinggi, dan sekaligus beriman dan beramal saleh dan punya keterampilan yang bersifan interprenership.

\section{Perguruan Tinggi STAI Nazhatut Thullab}

STAI Nazhatut Thullab adalah perguruan tinggi dibawah naungan yayasan pondok pesantren Nazhatut thullab sampang yang bertujuan untuk mengantarkan santri memiliki kematangan aqidah, kekhusu'an ibadah, dan keluhuran akhlak, sehingga terbentuk generasi yang islami dan intelek serta dapat berprestasi dalam rangka mengemban tugas sebagai hamba dan khalifah Allah di mukabumi.

Keberadaan dan sejarah Program Studi Pendidikan Sarjana (S1) dengan jurusan Pendidikan Agama Islam (PAI) di Sampang adalah dirintis oleh KH Muafi A. Zaini (Pengasuh Pondok Pesantren Nazhatut Thullab Prajjan Camplong Sampang) dengan mendirikan "Universitas Nazhatut Thullab" (UNAT) pada tahun 1987. Namun pendirian UNAT tersebut terkendala oleh syarat perizinan dengan minimal 6 Fakultas yang harus dimiliki untuk pendirian Universitas, sehingga pada tahun 1991 hanya 1 Prodi saja yang disetujui yakni Prodi Pendidikan Agama Islam (PAI), sehingga lahirlah STIT NAT (Sekolah Tinggi Ilmu Tarbiyah Nazhatut Thullab) Sampang, sesuai dengan keputusan Menteri Agama RI Nomor : 210 tahun 1991, tertangal 11 Desember 1991.

Pada tahun 2011, STIT Nazhatut Thullab beralih status lagi menjadi STAI Nazahtut Thullab (STAI NATA ) Sampang, sesuai dengan keputusan Direktur Pendidikan Islam nomor : Dj.I/1260/2011 tanggal 20 September 2011, dengan ditambah 1 Prodi/ Jurusan, yaitu; Prodi AS (Al-Akhwal Al-Syakhsyiyah) sesuai dengan surat keputusan Dirjen Pendidikan Islam nomor : Dj.I/1874/2011 tertanggal 28 Desember 2011, dan adanya penambahan prodi Ekonomi Syari'ah pada tahun 2012, sesuai dengan surat keputusan Dirjen Pendidikan Islam Nomor : 1891 tahun 2012 tertanggal 2 Oktober 2012.

Pada tahun 2014 menambah prodi Manajemen Pendidikan Islam (MPI) pada jurusan Tarbiyah. Selain itu, menambah jurusan dakwah dengan prodi Komonikasi dan Penyiaran Islam (KPI) dan sudah melalui proses visitasi prodi Bimbingan dan Konseling Islam (BKI) tinggal menunggu ijin operasional dari Direktur Jenderal Pendidikan Tinggi Islam Kemenag RI. Perguruan tinggi ini merupakan pengembangan dari lembaga pendidikan yang berada dibawah naungan yayasan pondok pesantren nazhatut thullab yang mana dalam pesantren tersebut sudah ada pendidikan formal maupun non formal. Dengan adanya perguruan tinggi ini santri paada khususnya dan masyarakat pada umumnya mendapat kemudahan untuk melanjutkan studinya kejenjang perguruan tinggi.

Adapun visi dan Misi dari STAI Nazhatut Thullab sampang adalah Mencetak Generasi Bangsa Berwawasan Ilmu Pengetahuan dan Teknologi serta menjunjung tinggi Akhlaqul Karimah. Dan misinya adalah Menyelenggarakan program pendidikan untuk mencetak lulusan yang unggul, berwawasan ilmiah serta mampu 
bersaing dalam konteks regional maupun nasional. Mengembangkan dan meyebarluaskan ilmu pengetahuan dan tekhnologi melalui penelitian dan publikasi ilmiah. Meningkatkan dan mengembangkan potensi Sumber Daya Manusia, sebagai integrasi pengetahuan teoritis dan praktis melalui pengabdian masyarakat. Dan tujuan kampus adalan Menghasilkan Sarjana Pendidikan Islam yang profesional dan akuntabel melalui proses pendidikan, penelitian dan pengabdian pada masyarakat. Menghasilkan konsep dan sumber belajar Pendidikan Agama Islam. Menghasilkan tenaga pendidik yang mampu meningkatkan kualitas pendidikan Islam. Menghasilkan tenaga Pendidik Agama Islam yang profesional, beriman dan berakhlaq karimah.

Proses dan perjalanan berdirinya STAI Nazhatut Thullab sebagai pengembangan pendidikan pesantren bukan suatu hal yang berdiri langsung menjadi STAI Nazhatu Thullab akan tetapi melalu tahapan dan proses yang mana sebelumnya adalah Universitas Nazhatut Thullab sampang. Kemudian dengan perjalan waktu dan ada penyesuaan serta undang-undang yang baru mengenai aturan perguruan tinggi ahirnya yang awalnya universitas kemudian ganti status menjadi STAI Nazhatu Thullab sampang.

Bicara tentang pendidikan, tampanya pendidikan tidak akan pernah selesai untuk dibicarakan. Pendidikan akan selalu terkait dengan kontektualitas kehidupan umat manusia sepanjang zaman. Setiap perkembangan peradaban umat manusia sudah barang tentu diikuti oleh berbagai dimensi kehidupan manusia itu sendiri, termasuk di dalamnya dimensi pendidikan. ${ }^{6}$ Integrasi ilmu dan agama akan semakin jelas jika kiata melihat, bahwa secara logis, pandangan seseorang tentang hubungan sains dengan agama niscaya dipengaruhi cara ia memandang sains(hakikatnya, metodenya,tujuannya)dan cara ia memandang agama. ${ }^{7}$ Dikotomi ilmu agama dan non-agama, sebenarnya bukan hal baru. Islam telah mempunyai tradisi dikotomi ini lebih dari seribu tahun silam. Tetapi dikotomi tersebut tidak menimbulkan terlalu banyak probem dalam system pendidikan islam, hingga system pendidikan sekuler barat diperkenalkan ke dunia islam melalui imprialisme. Hal ini terjadi karena, sekalipun dikotomi antara ilmu-ilmu agama dan non agama itu telah dikenal dalam karya-karya kelasik, seperti yang ditulis alGhazali. 8

Dari pendapat di atas dapat disimpulkan bahwa pendidikan adalah suatu proses bimbingan jasmani dan rohani yang berlandaskan ajaran Islam dan dilakukan dengan kesadaran untuk mengembangkan potensi anak menuju perkembangan yang maksimal, sehingga terbentuk keperibadian yang memiliki nilai-nilai Islam dan taat menjalankan ajaran Islam dalam kehidupan sehari-hari serta menjadikan agama Islam sebagai landasan etika dan moral dalam kehidupan bermasyarakat, berbangsa dan bernegara. ${ }^{9}$

\footnotetext{
${ }^{6}$ H. Darmadi, Integrasi Agama dan Ilmu Pengetahuan, (Yokyaarta: Diandra Kreatif, 2017)Hl:2

7 Zainal Abidin DKK, Integrasi Ilmu dan Agama:Interpretasi dan Aksi, (Bandung: Mizan Pustaka,2005) Hl.20

${ }^{8}$ Mulyadi Kartanegara, Integrasi Ilmu sebuah rekonstruksi holistic, (Bandung: Mizan Pustaka, 2005) Hl.19

${ }^{9}$ Moh. Wardi "Penerapan Nilai Pendidikan Agama Islam dalam Perubahan Sosian Remaja" Jurnal Tadrîs pendidkan agama islam STAIN PamekasanVolume 7 Nomor 1 Juni 2012, 33
} 


\section{Pemberdayaan Masyarakat}

Kemajuan pendidikan dan persaingan global baik perkembangan pembangunan yang berpusat pada manusia menekankan bahwa pembangunan bukan sekedar meningkatkan pertumbuhan ekonomi dan pendapatan nasional serta terpenuhinya kebutuhan dasar masyarakat, akan tetapi yang lebih penting lagi adalah pada upaya meningkatkan kualitas sumber daya manusia (SDM) agar dapat meningkatkan keikutsertaan masyarakat secara nyata dalam berbagai aktifitas kehidupan untuk mendorong terciptanya kegiatan produktif yang bernilai tinggi. Dalam hal ini perlu adanya perhatian khusus dari pihak adademisi pendidkan dalam upaya mengembangkan rasa keefektifan yang akan mengubah pola pikir masyarakat agar bisa menjadi masyarakat yang dapat memberikan kontribusinya dalam proses pembangunan dan mampu bersaing dilevel regional maupun internasional baik yang berkenaan dengan peniningkata mutu pendidikan maupun kesejehteraan dalam bidang ekonomi.

Pemberdayaan masyarakat dalam kata lain pengembangan sumberdaya manusia melalui jalur pendidikan formal yang perlu dilakuan adalah sebagai berikut. Pertama, pendidikan harus diorientasikan keada pencapaian tujuan pendidikan nasional secara efektif dan efisien, yaitu perkembangan potensi peserta didik agar dapat menjadi manusia yang beriman dan bertaqwa kepada tuhan yang maha Esa, berakhlak mulia, sehat, berilmu, cakap, reatif, mandiri dan menjadi warga Negara yang demokratis dan bertanggung jawab. Kedua, menumbuhkan budaya belajar kepada seluruh lapisan masyarakat. Sebab melalui budaya belajar menyebabkan standart yang tinggi dalam pendidikan dan mutu sumber daya manusia. ${ }^{10}$ Pemberdayaan itu adalah sebuah "proses menjadi", bukan sebuah "proses Instan". Sebagai proses, pemberdayaan mempunyai tiga tahapan: penyadaran, pengkapasitasan, dan pendayaan. ${ }^{11}$ MSDM dewasa ini mendapat sorotan tajam dari berbagai pihak. Sumberdaya manusia mempunyai dampak yang lebih besar terhadap efektifitas organisasi disbanding dengan sumberdaya yang lain. Seberapa baik sumber daya manusia dikelola akan menentukan esuksesan masyarakat dimasa yang akan dating. ${ }^{12}$ Untuk menjawb persoalan social dan lingkungan di mana manusia hidup diperlukan generasi yang siap menjawab tantangan dan menemukan jalan keluar dari berbagai krisis yang saat ini sudah terjadi dan bahkan akan terjadi sepuluh atau dua puluh tahun kedepan. Melalui metode ilmiah, santri sejak didi diajarkan untuk kritis terhadap fenomina di sekitarnya, dari apa yang dilihat dan dibacanya. ${ }^{13}$

\section{Perspektif Manajemen}

Manajemen menurut James A. F. Stoner "Manajemen is the process of planning, organizing, leading and controlling the effort of organizational members and the use of other organizational resources in other to achieve stated

\footnotetext{
${ }^{10}$ Syafaruddin, Pendidikan dan pPemberdayaan Masyarakat, (Medan: Perdana Publising, 2012) Hl.19

${ }^{11}$ Randy R. Wrihatnoyo, Riant Nogroho Dwidjowijoto, Manajemen Pemberdayaan, sebuah pengantar dan panduan untuk pemberdayaan masyaraka, (Jakarta: Media Kopotindo, 2007)Hl.2

${ }^{12}$ I Gusti Ketut Purnaya, Manajemen Sumber daya manusia, (Yokyakatra: Andi Offset, 2016)Hl,3

${ }^{13}$ Jejen Musfah, Manajemen Pendidikan, Teori, Kebijakan, dan Praktik, (Jakarta: Fajar Intrapratama Mandiri, 2017) hl. 129
} 
organizational goals" yaitu: manajemen adalah proses perncanaan, pengorganisasian, pemberi pimpinan, dan pengendalian dari suatu usaha dari anggota organisasi dan penggunaan sumber-sumber daya organisatoris untuk mencapai tujuan organisasi yang telah ditetapkan.

Secara etimologis, manajemen dapat diartikan sebagai suatu proses penataan dengan melibatkan sumber-sumber potensial, baik yang bersifat manusia maupun yang bersifat non manusia dalam rangka mencapai tujuan secara efektif dan efisien. Lebih jelas lagi manajemen diartikan dengan suatu proses yang membedabedakan antara perencanaan, pengorganisasian, penggerakan, pelaksanaan dan pengawasan dengan memanfaatkan ilmu pengetahuan atau seni, agar dapat menyelesaikan tujuan yang telah ditetapkan sebelumnya. Dalam devinisi ini, manajemen dipandang sebagai suatu proses mulai dari tahap perencanaan, pengorganisasian, penggerakan, pelaksanaan sampai pada pengawasan. ${ }^{14}$

Pengertian manajemen adalah suatu proses perencaan, pengorganisasian, leadership, serta pengendalian upaya dari anggota organisasi tersebut serta penggunaan Sumber daya yang tersedia di organisasi tersebut guna mencapai suatu tujuan yang telah ditetapkan organisasi sebelumnya. Dan utuk lebih jelasnya peneliti akan memberikan penjelasan tentang pengerian manajemen dari beberapa ahli.

Manajemen menurut Koontz dan Cyril O'donnel: Manajemen adalah usaha untuk mencapai/menggapai tujuan tertentu melalui kegiatan/usaha orang lain. Menurut R.Terry: Manajemen adalah suatu proses unik dan khas yang terdiri atas tindakan-tindakan perencanaan, pengorganisasian, serta penggerakan dan pengendalian yang dilakukan guna menentukan arah serta mencapai tujuan yang telah ditentukan sebelumnya melalui pemanfaatan SDM serta sumber daya lain. Menurut Lawrence A.Appley: Manajemen adalah seni untuk mencapai tujuan tertentu yang dilakukan oleh orang lain/usaha orang lain. Menurut Drs/ Oey Liang Lee: Manajemen adalah ilmu dan seni perencaan, pengorganisasian, pengarahan, serta pengawasan terhadap SDM guna mencapai tujuan tertentu yang telah ditentukan. Menurut James A.F.Stoner: Manajemen adalah suatu proses perencaan, pengorganisasian, leadership, serta pengendalian upaya dari anggota organisasi tersebut serta penggunaan Sumber daya yang tersedia di organisasi tersebut guna mencapai suatu tujuan yang telah ditetapkan organisasi sebelumnya. Menurut Mary Parker Follet: Manajemen adalah seni, karena untuk melakukan/ menyelesaikan pekerjaan tertentu yang dilakukan oleh orang lain membutuhkan keterampilan tertentu. Menurut Hilman: Manajemen adalah fungsi untuk mencapai suatu tujuan melalui perantara kegiatan orang lain serta mengawasi usaha-usaha setiap individu guna mencapai tujuan yang sama. Menurut Encyclopeia of The Social Science: Manajemen adalah suatu proses pelaksanaan untuk mencapai tujuan tertentu yang diselenggarakan dan diawasi. Manajemen menurut G.R. Terry: Manajemen adalah suatu kerangka kerja/proses yang membutuhkan pengarahan dan bimbingan suatu kelompok orang-orang untuk mencapai tujuan organisasi yang nyata. Manajemen menurut Ricky W. Griffin Manajemen adalah proses perencanaan/planning, pengorganisasian,

\footnotetext{
${ }^{14}$ M. Rokib, Manajemen Pendidikan Dalam Peningkatan Mutu Pendidikan Islam. (Tesis, STAI AlKoziny Sidoarjo, 2008)
} 
pengkoordinasisasian, serta pengontrolan setiap sumber daya yang ada guna mencapai tujuan ataupun goals yang telah ditentukan dengan efektif dan efisien. Efektif berarti tujuan dapat dicapai sesuai dengan rencana yang ada, dan efisien berarti dilaksanakan dengan benar dan terorganisis yang sesuai dengan jadwal yang telah ditentukan.Menurut Henry Fayol: Manajemen adalah ilmu yang mengandung gagasan/ide 5 fungsi utama yaitu merancang, memerintah, mengorganisasi, mengendalikan dan mengoordinasasi. Menurut Chaster I Bernard: Manajemen adalah seni dan ilmu. Menurut Federick Winslow Taylor: Manajemen adalah sebuah percobaan yang dilakukan secara sungguh-sungguh guna menghadapi setiap persoalan yang muncul dalam setiap kepemimpinan perusahaan/organisasi lain/setiap sistem kerjasama yang dilakukan setiap manusia dengan sikap serta jiwa seorang sarjana serta penggunaan alat-alat perumusan. Menurut Lyndak F.Urwick: Manajemen adalah meramalkan/ forecasting, perencaan pengorganisiran/planning orga-nizing, memerintahkan/ commanding, pengkoordinasian/coordinationg serta pengontrollan/controlling. Menurut Prof. Eiji Ogawa: Manajemen adalah perencaan, pengimplementasian serta pengendalian dari setiap kegiatan termasuk didalamnya pembuatan barang yang dilakukan oleh setiap organisasi usaha dengan sebelumnya sudah menetapkan setiap sasaran/tujuan untuk kerja yang disempurnakan sesuai dengan kondisi (fleksibel). Menurut Dr. Ahuja: Manajemen adalah pihak-pihak yang menawarkan/menyediakan jasa untuk bidang yang berhubungan dengan manajemen. Menurut Renville Siagian: Manajemen adalah salah satu bidang usaha yang bergerak di bidang jasa pelayanan yang dikelola oleh tenaga ahli yang terlatih dan berpengalaman. Menurut Dr. Bennett N.B Silalahi, M.A: Manajemen adalah ilmu perilaku yang teridiri dari aspek sosial eksak bukan dai tanggungjawab keselamatan serta kesehatan kerja baik dari sisi perencaannya. Menurut William H.Newman: Manajemen adalah fungsi yang saling berhubungan untuk mencapai hasil tertentu melalui orang lain. Menurut Drs. Oey: Manajemen adalah perencaan/planning, pengorganisasian/organizing, pengarahan, pengkoordinasian serta pengontrollan.

\section{Kesimpulan}

Dari beberapa uraian dan pandangan serta analisis peneliti bahwa untuk mewujudkan visi dan misi pesantren Nazhatut Thullab dan STAI Nazhatut Thullab sampang bukanlah hal yang instan, akan tetapi untuk membangun sebuah institusi atau lembaga tertentu di butuhkan unsur-unsur manajemen seperti halnya perencanaan, organisir, kontroling atau monitoring dan evaluasi seperti apa yang telah dilakukan oleh pengelola Pesantren Nazhatut Thullab dan STAI Nazhatut Thullab Sampang dalam membangun sinerjitas pendidikan pesantren dan perguruan tinggi dalam pemberdayaan masyarakat.

Sistem pendidikan pesantren serta STAI Nazhatut Thullab sampang merupakan bagian yang tidak bisa dipisahkan, hanya dalam pengaturan pesantren dan perguruan tinggi mempunyai alur (regulasi) tersendiri. Keberadaan pesantren dan perguruan tinggi Nazhatut Thullab sampang merupakan bagian integral yang tidak dapat dipisahkan dari program dan kesamaan visi dan misi dalam upaya mensinergikan pandangan akademisnya. dengan demikian akan menghasilkan miliu yang sangat membantu pencapaian visi, misi dan target institusi. Dengan 
kata lain, keberadaan STAI Nazhatut Thullab samapang sebagai satu buah sistem turut menjaga agar visi, misi dan strategi yang dilakukan oleh Pesantren secara umum selalu selalu sejalan. Dalam perkembangannya, banyak santri pesantren Nazhatut Thullab yang melanjutkan pendidikannya ke STAI Nazhatut Thullab sampang. untuk terus membangun hubungan yang harmusis, maka dibutuhkan pengelolaan yang profesional baik dari segi penanganan sarana prasarana fisik dan nonfisik maupun SDM para pengelolanya.

Tekad STAI Nazhatut Thullab sampang untuk menjadi perguruan tinggi yang maju serta memberikan energi positif sekaligus tantangan bagi STAI Nazhatut Thullab. Energi positif yang dimaksud adalah out put yang dihasilkan menjadi semakin kompetitif dan selektif, sedangkan tantangannya berupa input mahasiswa yang heterogen tentunya harus mendapatkan penanganan dan manajemen yang tepat dari para pengelola kampus. Karena niat yang kuat tidak cukup jika tidak disertai komitmen dan konsistensi yang kuat dari para pengelola kampus ini, terutama para akademisi perguruan tinggi, Dosen, karyawan dan semua civitas institusi.

\section{Daftar Pustaka}

Abidin, Zainal. DKK, Integrasi Ilmu dan Agama:Interpretasi dan Aksi, (Bandung: Mizan Pustaka,2005).

Darmadi, H. Integrasi Agama dan Ilmu Pengetahuan, (Yokyaarta: Diandra Kreatif, 2017).

Kartanegara,Mulyadi. Integrasi Ilmu sebuah rekonstruksi holistic, (Bandung: Mizan Pustaka, 2005).

Mastuhu. Memberdayakan Sistem Pendidikan Islam,(Jakarta: PT Logos Wacana Ilmu,1999)

Moh wardi. "Problematika Pendidikan Islam dan solusi alternatifnya, (Perspektif Ontologis, Epistimologis dan Aksiologis)"Jurnal Tadrîs pendidkan agama islam STAIN Pamekasan Volume 8 Nomor 1 Juni 2013.

Mufid, Fathul. “Integrasi Ilmu-ilmu Islam”Volume 1, No.1, Juni 2013.

Moh. Wardi. "Penerapan Nilai Pendidikan Agama Islam dalam Perubahan Sosian Remaja" Jurnal Tadrîs pendidkan agama islam STAIN PamekasanVolume 7 Nomor 1 Juni 2012.

Musfah, Jejen. Manajemen Pendidikan, Teori, Kebijakan, dan Praktik, (Jakarta: Fajar Intrapratama Mandiri, 2017).

Purnaya,I Gusti Ketut. Manajemen Sumber daya manusia, (Yokyakatra: Andi Offset, 2016).

R. Wrihatnoyo, Randy. Riant Nogroho Dwidjowijoto, Manajemen Pemberdayaan, sebuah pengantar dan panduan untuk pemberdayaan masyaraka, (Jakarta: Media Kopotindo, 2007).

Rokib, M. Manajemen Pendidikan Dalam Peningkatan Mutu Pendidikan Islam. (Tesis, STAI Al-Koziny Sidoarjo, 2008)

Sahibuddin, M. "Pesantren dan Pendidikan Tinggi" Jurnal Penelitian dan Pemikiran Keislam, Juli 2017.Vol.4.No.2,

Syafaruddin. Pendidikan dan pPemberdayaan Masyarakat, (Medan: Perdana Publising, 2012). 